\title{
Brief Report \\ Detection and Molecular Characterization of Canine Alphacoronavirus in Free-Roaming Dogs, Bangladesh
}

\author{
Mohammad Enayet Hossain ${ }^{1}$ (D) Ariful Islam ${ }^{2,3,4, *(D)}$, Shariful Islam ${ }^{2,4}{ }^{\mathbb{D}}$, Md Kaisar Rahman ${ }^{2,4}{ }^{\mathbb{D}}$, Mojnu Miah $^{1}$, \\ Md Shaheen Alam ${ }^{1}$ and Mohammed Ziaur Rahman ${ }^{1}{ }^{1}$
}

1 International Centre for Diarrhoeal Diseases Research, Bangladesh (icddr,b), Dhaka 1212, Bangladesh; enayet.hossain@icddrb.org (M.E.H.); mojnu.miah@icddrb.org (M.M.); shaheen.alam@icddrb.org (M.S.A.); mzrahman@icddrb.org (M.Z.R.)

2 EcoHealth Alliance, New York, NY 10001-2320, USA; sharifdvm51@gmail.com (S.I.); kaisar.kaif@gmail.com (M.K.R.)

3 Centre for Integrative Ecology, School of Life and Environmental Science, Deakin University, Burwood, VIC 3216, Australia

4 Institute of Epidemiology, Disease Control and Research (IEDCR), Mohakhali, Dhaka 1212, Bangladesh

* Correspondence: arif@ecohealthalliance.org

check for updates

Citation: Hossain, M.E.; Islam, A.; Islam, S.; Rahman, M.K.; Miah, M.; Alam, M.S.; Rahman, M.Z. Detection and Molecular Characterization of Canine Alphacoronavirus in Free-Roaming Dogs, Bangladesh. Viruses 2022, 14, 67. https: / / doi.org/10.3390/v14010067 Academic Editors: Chao-Nan Lin and Peck Toung Ooi

Received: 2 November 2021 Accepted: 28 December 2021 Published: 30 December 2021

Publisher's Note: MDPI stays neutral with regard to jurisdictional claims in published maps and institutional affiliations.

Copyright: () 2021 by the authors Licensee MDPI, Basel, Switzerland. This article is an open access article distributed under the terms and conditions of the Creative Commons Attribution (CC BY) license (https:// creativecommons.org/licenses/by/ $4.0 /)$.

\begin{abstract}
Canine coronavirus $(\mathrm{CCOV})$ is widespread among the dog population and causes gastrointestinal disorders, and even fatal cases. As the zoonotic transmission of viruses from animals to humans has become a worldwide concern nowadays, it is necessary to screen free-roaming dogs for their common pathogens due to their frequent interaction with humans. We conducted a cross-sectional study to detect and characterize the known and novel Corona, Filo, Flavi, and Paramyxoviruses in free-roaming dogs in Bangladesh. Between 2009-10 and 2016-17, we collected swab samples from 69 dogs from four districts of Bangladesh, tested using RT-PCR and sequenced. None of the samples were positive for Filo, Flavi, and Paramyxoviruses. Only three samples (4.3\%; 95\% CI: 0.9-12.2) tested positive for Canine Coronavirus $(\mathrm{CCoV})$. The $\mathrm{CCoV}$ strains identified were branched with strains of genotype CCoV-II with distinct distances. They are closely related to CCoVs from the UK, China, and other $\mathrm{CoVs}$ isolated from different species, which suggests genetic recombination and interspecies transmission of CCoVs. These findings indicate that $\mathrm{CCoV}$ is circulating in dogs of Bangladesh. Hence, we recommend future studies on epidemiology and genetic characterization with full-genome sequencing of emerging coronaviruses in companion animals in Bangladesh.
\end{abstract}

Keywords: Bangladesh; canine; coronavirus; epidemiology; zoonotic

\section{Introduction}

Coronavirus (CoV) is an enveloped, non-segmented, single stranded RNA virus classified under the family Coronaviridae. This family hosts several human and animal CoVs which affect both respiratory and enteric systems. Under the subfamily Coronavirinae, there are four genera: Alphacoronavirus $(\alpha-\mathrm{CoV})$, Betacoronavirus $(\beta-\mathrm{CoV})$, Gammacoronavirus and Deltacoronavirus [1-3]. Human and other mammalian species generally become infected by all four genera of CoVs, while avian species only by Gammacoronavirus and Deltacoronavirus [4]. In the recent past, the world has faced CoV outbreaks belonging to Betacoronavirus (SARS-CoV-1, MERS-CoV, SARS-CoV-2 etc.) $[5,6]$. The current SARS-CoV2 and previous SARS-CoV-1 and MERS-CoV zoonotic coronaviruses that have recently transferred from animal to human populations all belong to the $\beta$-CoVs [4]. CoVs are capable of causing, variably, severe intestinal, respiratory, neurologic, or systemic disease syndromes and finally death [4,7]. Recently SARS CoV-2 has been identified in dogs, lions, and tigers from different countries, inferring that they might have been transited from infected humans [8-10]. Beyond SARS CoV-2, Canine coronavirus (CCoV) belongs to $\alpha-\mathrm{CoV}$, and canine respiratory coronavirus $(\mathrm{CRCoV})$ belongs to $\beta-\mathrm{CoV}$, but both can infect 
dogs [3]. A study released on 20 May 2021 investigated samples collected between 2017 and 2018 from eight patients with pneumonia (seven of whom were children) in Malaysia and discovered a new coronavirus strain CCoV-HuPn-2018 [11]. Another sequence of CCoV strain Z19 (MZ420153) was found in a NCBI database which was detected in a Haitian human in 2017 [12]. If the association of $\mathrm{CCoV}$ with human disease is confirmed, it would become the eighth known coronavirus to cause human disease.

Based on spike protein amino acid sequences, $\mathrm{CCoVs}$ are classified into two distinct genotypes, named CCoV-I and CCoV-II [13]. CCoV-II can be further divided into CCoVIIa and CCoV-IIb. CCoV type I is genetically more similar to feline coronavirus (FCoV) type I than to CCoV type II. On the other hand, FCoV type II evolved by heterologous recombination between CCoV type II and FCoV type I [14].

$\mathrm{CCoV}$ is considered to be responsible for gastrointestinal infection in dogs; more precisely, young puppies are most susceptible $[15,16]$. Usually, coronavirus replicates in enterocytes of the tip of the intestinal villus and causes a varying degree of enteritis and shedding of virus for a long period through feces $[17,18]$. It leads to lethargy, anorexia, vomiting, diarrhea, dehydration, and lymphopenia lasting for 1-2 weeks in dogs $[15,16]$.

$\mathrm{CCoV}$ is highly contagious but sometimes it causes asymptomatic infection and occasionally causes death in young puppies, particularly co-infected with other pathogens such as canine parvovirus $[13,16]$. Hence, the symptoms of infected dogs depend on the age of the animals, level and type of infected organism, and immunity developed by maternal antibodies [13]. The virus can cause respiratory distress and has been previously detected from respiratory samples $[19,20]$. CCoV has been identified at high prevalence in kenneled dogs than in other types of dog. The prevalence was not strongly associated with age, sex, breed, and health condition [21]. However, the infection depends on dog management practices [22].

The exact number of dogs in Bangladesh is still unknown. But it was found that $64 \%$ of all dogs in Bangladesh are stray dogs and another 30\% were estimated as unrestricted neighborhood dogs [23]. There are approximately $14 \mathrm{dogs} / \mathrm{km}^{2}$ and the human-dog ratio is 120:1 [24]. Another study estimated that there are a total of 18,585 free-roaming/stray dogs in Dhaka city (52 dogs $/ \mathrm{km}^{2}$ ) where the human-dog ratio is $828: 1$ [25]. Stray dogs roam around public places and search for food in wastage or garbage. These stray dogs have frequent interaction with humans, especially with children who live in slums [23]. Distribution of street dogs and their foraging behavior are closely linked with the cultural and socioeconomic conditions of humans [25]. These free-roaming dogs can be a source of serious health hazards for humans. Transmission of emerging zoonotic pathogens like SARS-CoV and MERS-CoV from animal host to human has been a concern worldwide [26,27]. It is crucial to detect and characterize the novel virus circulating animal host and stop spillover to humans at high interfaces and to prevent future epidemics and pandemics by disease X. Coronavirus [21,28,29], Filovirus [30], Flavivirus [31,32], and Paramyxoviruses [33-35] have been identified in dogs in other countries, but Bangladesh lags behind in this aspect. Therefore, it is crucial to know the viral diversity in dog populations, molecular characterization, and phylogenetic analysis of the circulating strains. The study aimed to detect and characterize the known and novel Corona, Filo, Flavi, and Paramyxoviruses in free-roaming dogs in Bangladesh.

\section{Materials and Methods}

\subsection{Study Location and Duration}

We conducted a cross-sectional study in four districts of Bangladesh (Chattogram, Dhaka, Pabna, and Rajshahi) during the dry season (November to April) and wet season (May to October) between 2009-10 and 2016-17 (Figure 1). We sampled a total of 69 dogs from the city corporation area of the study districts. 


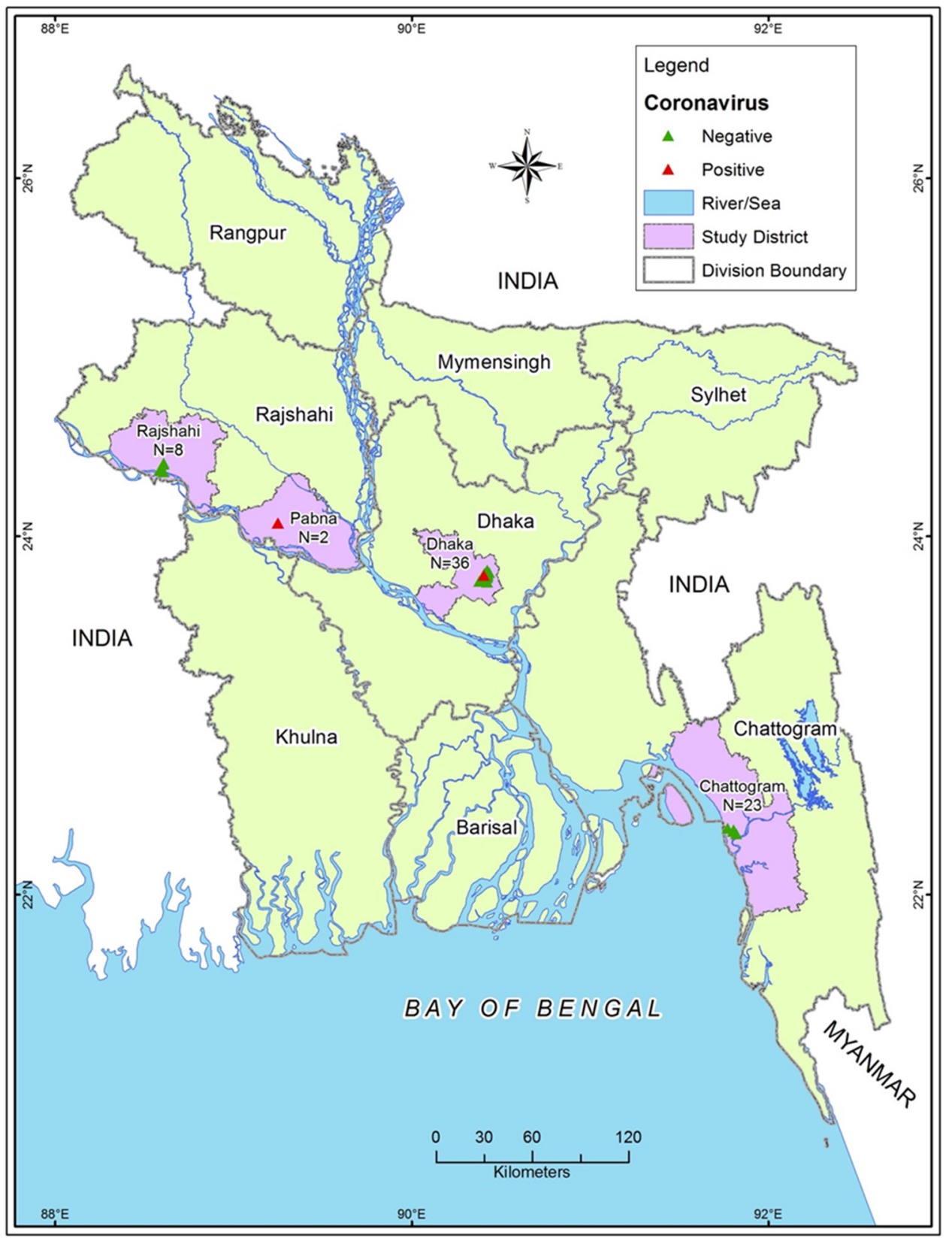

Figure 1. Sampling sites and sample numbers from 4 study districts.

\subsection{Dog Capturing, Sample Collection and Processing, Data Collection}

We captured and restrained stray dogs (have no owner) and sheltered dogs (have an owner but can mix with stray dogs) according to the safe animal capture and sampling protocol of USAID PREDICT (PREDICT One Health Consortium 2016) [36-38]. Physical restraining was accomplished with full personal protective equipment including nitrile gloves, N95 mask, goggles, Tyvek type suits, and specialized equipment such as leather gloves and rabies-poles [36]. We collected oropharyngeal swab and rectal swab samples from each dog. Samples were kept in two aliquots in $500 \mu \mathrm{L}$ trizol or lysis buffer and $500 \mu \mathrm{L}$ viral transport media (VTM). Immediately after sample collection, we released the animals at their capturing sites. All samples were stored in liquid nitrogen in the field and transferred to laboratory for storage in $-80^{\circ} \mathrm{C}$ freezer until further analysis. The team collected the necessary information for individual dogs such as age, sex, breed, health condition (healthy or sick), body condition score (BCS), and physical examination findings using a structured multiple-choice questionnaire. To determine age, we checked the 
dentition, physical growth, and external genital organs [36,39-41]. For BCS, we inspected the visible body fat coverage, following International Companion Animal Management guidelines and categorized as poor (emaciated), fair (underweight) and good (normal, overweight or obese) [42].

\subsection{Laboratory Analysis}

We tested the samples for Corona, Filo, Flavi, and Paramyxovirus. After extraction of RNA, we synthesized cDNA using the SuperScript III RNase H Reverse transcriptase kit (Invitrogen SA, Spain/Portugal, Barcelona, Spain). Filovirus, Flavivirus, and Paramyxovirus were screened according to the procedure described by Moureau and Temmam [43], Zhai and Palacios [44] and Tong and Chern [45] protocols, respectively.

Two conventional PCR techniques were used targeting non-overlapping fragments of the orf1ab to identify known and novel coronaviruses [46,47]. We used a heminested PCR to amplify the highly conserved region of the RNA-dependent RNA polymerase (RdRp) gene ( $434 \mathrm{bp}$ ) corresponding to nucleotides (NTs) 14,123-14,556 in the canine coronavirus strain 2020/7 genome (MT906865) following Watanabe et al. [47] with some modifications. Quan et al. [46] amplified a 328 bp fragment of nsp14 gene corresponding to NTs 17,282-17,609 in the canine coronavirus strain 2020/7 genome (MT906865).

According to the traditional Sanger dideoxy sequencing, amplified products of the expected size were sequenced and further edited manually in Geneious Pro (version 9.1.3, Biomatters, Auckland, New Zealand). All gene sequences generated in the study were submitted to the GenBank database.

We searched for highly similar sequences to our sequences in GenBank using the Basic Local Alignment Search Tool (BLAST). Sequences that have $>90 \%$ similarities with a sequence already in GenBank are considered as a known virus [48]. RdRp and Nsp14 gene sequences of different reference strains of Feline coronavirus (FCoV), porcine transmissible gastroenteritis virus (TGEV), and canine coronavirus (CCoVs) were retrieved from the National Center for Biotechnology Information (NCBI). All the retrieved sequences were aligned with Bangladeshi $\mathrm{CCOV}$ sequences by subjecting to ClustalW multiple sequence alignment using BioEdit 7.1.3 program [49]. Evolutionary relationships were inferred by using the Maximum Likelihood method based on the Hasegawa-Kishino-Yano model [50] from 1000 bootstrap values. The evolutionary distances were computed using the Kimura 2-parameter method, and evolutionary analyses were conducted in MEGA 7.

To better visualize the genetic relatedness of viruses, a median-joining phylogenetic network was constructed based on the partial RdRp gene by using NETWORK version 10.1 with epsilon set to 0 (www.fluxus-engineering.com, accessed on 13 December 2021). To generate a phylogenetic network, $\mathrm{CCoV}$ and $\mathrm{FCoV}$ sequences were subjected to ClustalW multiple sequence alignment using BioEdit 7.1.3 program [49] and a haplotype data file was generated using the DNA sequence polymorphism analysis tool DnaSP (http:/ / www. ub.edu/dnasp/, accessed on 13 December 2021).

\subsection{Statistical Analysis}

We used Microsoft Office Excel 2013 (Redmond, WA, USA) for data entry and management while STATA-13 (StataCorp 4905, Lakeway Drive, College Station, TX 77845, USA) was used for data analysis. A dog was considered positive if any of the 3 samples from each dog was tested positive in either protocol of PCR for CoV $[46,47]$. Descriptive analysis was done to summarize frequency and percentage with $95 \%$ confidence interval (CI).

\section{Results}

None of the samples were found positive for Filo, Flavi and Paramyxovirus. Among 69 street dogs, $4.3 \%(n=3$; 95\% CI: $0.9-12.2)$ were positive for coronavirus. CoV positive samples were from Dhaka $(n=1,2.8 \% ; 95 \%$ CI: $0.07-14.5)$ and Pabna $(n=2 ; 100 \% ; 95 \%$ CI: 15.8-100), sampled in dry season $(n=3 ; 18.8 \%$; 95\% CI: 4.0-45.6). All three positive dogs were adult ( $n=3 ; 23.1 \% ; 95 \%$ CI: 5.0-53.8), two were female ( $n=2 ; 6.1 \%$; 95\% CI: 0.7-20.2) 
and one was male $(n=1 ; 2.8 \% ; 95 \%$ CI: $0.07-14.5)$. The positive dogs had fair $(n=1 ; 3.5 \%$; 95\% CI: 0.08-17.8) and poor body condition $(n=2 ; 9.1 \% ; 95 \%$ CI: $1.1-29.1)$ (Table 1$)$.

Table 1. Distribution of canine coronavirus in Dogs, Bangladesh.

\begin{tabular}{|c|c|c|c|c|}
\hline Variables & Categories & $\mathbf{N}$ & $\begin{array}{c}\text { CCoV Positive } \\
n(\%)\end{array}$ & $95 \%$ CI \\
\hline \multirow{4}{*}{ District } & Chattogram & 23 & - & - \\
\hline & Dhaka & 36 & $1(2.8)$ & $0.07-14.5$ \\
\hline & Pabna & 2 & $2(100)$ & 15.8-100 \\
\hline & Rajshahi & 8 & - & - \\
\hline \multirow{2}{*}{ Sampling time } & 2009-2010 & 53 & - & - \\
\hline & 2016-2017 & 16 & $3(18.8)$ & $4.0-45.6$ \\
\hline \multirow{2}{*}{ Sampling season } & Dry & 16 & 3 (18.8) & $4.0-45.6$ \\
\hline & Wet & 53 & - & - \\
\hline \multirow{2}{*}{ Sex } & Male & 36 & $1(2.8)$ & $0.07-14.5$ \\
\hline & Female & 33 & $2(6.1)$ & $0.7-20.2$ \\
\hline \multirow{3}{*}{ Age } & $1-1.5$ years & 32 & - & - \\
\hline & 1.6-3 years & 24 & - & - \\
\hline & $>3$ years & 13 & $3(23.1)$ & $5.0-53.8$ \\
\hline \multirow{2}{*}{ Type of ownership } & Stray dog & 58 & $2(3.5)$ & $0.4-11.9$ \\
\hline & Sheltered dog & 11 & $1(9.1)$ & $0.2-41.2$ \\
\hline \multirow{2}{*}{ Health condition } & Sick & 13 & $1(7.7)$ & $0.2-36.0$ \\
\hline & Apparently healthy & 56 & $2(3.6)$ & $0.4-12.3$ \\
\hline \multirow{3}{*}{$\mathrm{BCS}$} & Poor & 22 & $2(9.1)$ & $1.1-29.1$ \\
\hline & Fair & 29 & $1(3.5)$ & $0.08-17.8$ \\
\hline & Good & 18 & - & - \\
\hline
\end{tabular}

The three positive samples were from rectal samples of dogs. The samples tested positive in both protocols used in this study. Therefore, we obtained six sequences from three rectal swab samples. All gene sequences generated in the study were submitted to the GenBank database under the accession numbers MT083414, MT083415, MT083436, MT064650, MT064651, and MT064809. The sequences have $97.24 \%$ similar identity with canine coronaviruses.

Phylogenetic analysis using partial RdRp genes showed that Bangladeshi CCoV strains are branched in cluster I of canine coronavirus type II. All CCoV strains isolated from dogs: BDADP-01, BDADP-02, and BDADAIDP-006 belong to the CCoV-II group. Of them, two CCoV-II strains BDADP-01, BDADP-02 collected from Pabna district, branched in cluster I. Another CCoV-II strain BDADAIDP-006 collected from Dhaka, formed a close cluster with CCoV strain 2020/7 (MT906865), Raccoon dog CoV strain GZ43/03 (EU769559), civet coronavirus strain D690/05 (EF584903), and CCoV strain B135_JS_2018 (MT114544), shared $>98 \%$ nucleotide identities (Figure 2). Bangladeshi CCoV strains exhibited $96.3-100 \%$ nucleotide identities. The sequence comparison of the partial RdRp gene revealed amino acid homology of 100\% among three Bangladeshi CCoV strains and with other type II CCoVs within cluster I. Two CCoV-II strains isolated from humans in Malaysia (MW591993) [10] and Haiti (MZ420153) showed 93.77-94.5 nucleotide identities and $100 \%$ amino acid homology with Bangladeshi CCoVs detected in dogs. 


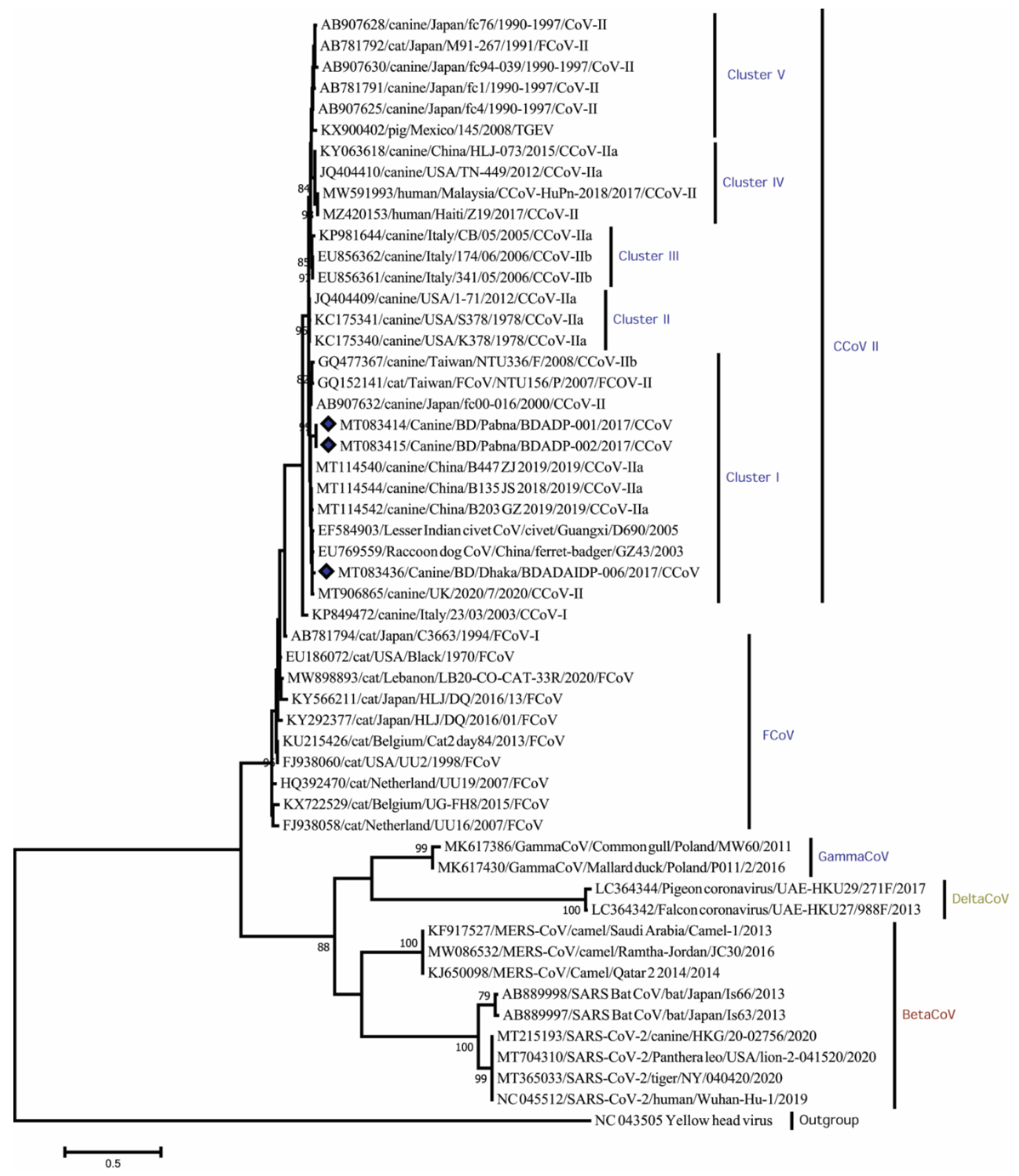

Figure 2. Maximum Likelihood phylogenetic tree based on the partial RdRp sequence of Coronaviridae. CCoV strains in this study are indicated by rhombus (blue colored). The tree was calculated using the Maximum Likelihood method with the Kimura 2-parameter distance model. The percentages of replicate trees $(>70 \%)$ in which the associated taxa clustered together in the bootstrap test (1000 replicates) are shown next to the branches. RdRp, RNA dependent RNA polymerase; $\mathrm{CCoV}$, canine coronavirus; CCoV-I, canine coronavirus type I; CCoV-II, canine coronavirus type II; CCoV-IIa, canine corona-virus subtype IIa; CCoV-IIb, canine coronavirus subtype Ilb; FCoV, feline coronavirus.

Phylogenetic analysis revealed that Nsp14 genes of three CCoV strains clustered closely within themselves and with other CCoV-II strains (Figure 3). Amino acid sequence comparison unveiled homologies of 97.94-98.97\% (K176R, S185A/T variations) with other CCoV-II strains as well as $98.97 \%$ (S185A/T variation) with CCoV-II strains isolated from humans. 


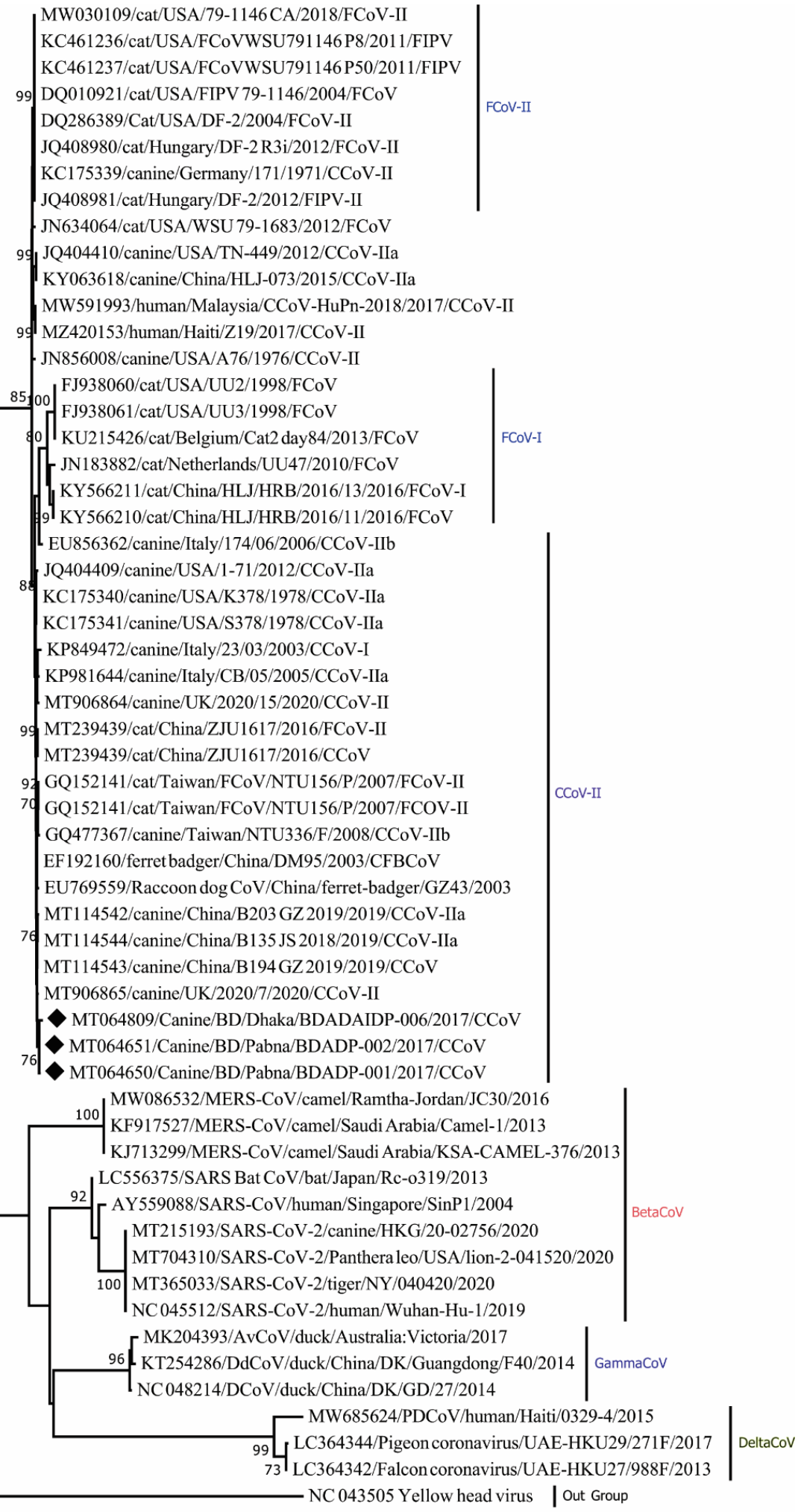

Figure 3. Maximum Likelihood phylogenetic tree based on the partial nonstructural protein 14 (Nsp14) sequence of Coronaviridae. CCoV strains in this study are indicated by rhombus (blue colored). Canine $\mathrm{CoV}$, feline $\mathrm{CoV}$, Betacoronavirus, Gammacoronavirus, Deltacoronavirus sequences are shown in the phylogeny. The tree was calculated using the Maximum Likelihood method with the Kimura 2-parameter distance model. The percentages of replicate trees $(>70 \%)$ in which the associated taxa clustered together in the bootstrap test (1000 replicates) are shown next to the branches. 
Median-joining phylogenetic network analysis demonstrated that the studied CCoVs strains formed separate nodes within other CCoV-II strains from China and Europe which confirmed the presence of type II CCoV strains in Bangladesh (Figure 4). Network analysis findings support the result of the evolutionary phylogeny analysis.
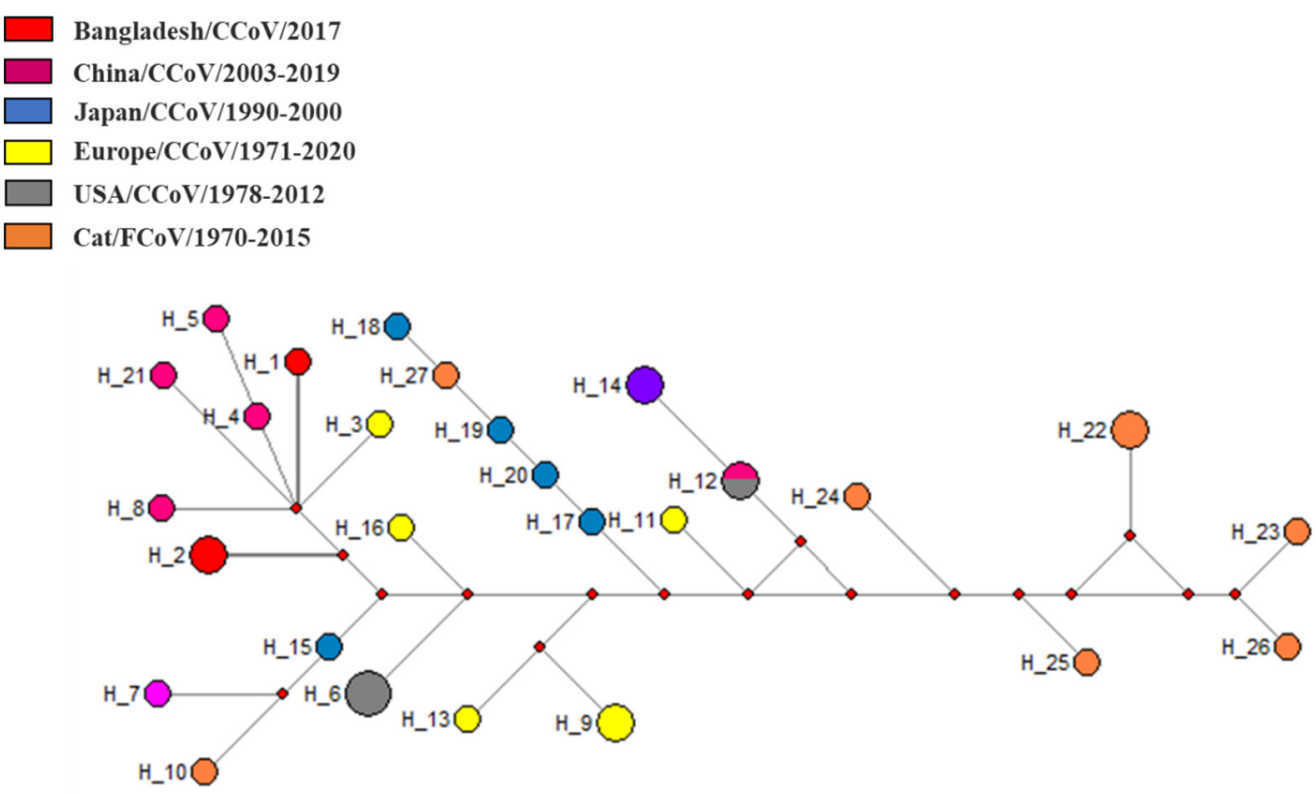

Figure 4. Median-joining phylogenetic network of Coronaviridae. The median-joining network was constructed from the partial RdRp sequences. Each unique sequence is represented by a circle sized relative to its frequency in the dataset. Isolates are colored according to the location. RdRp, RNA-dependent RNA polymerase.

\section{Discussion}

To the author's knowledge, we screened free-roaming dogs for Corona, Filo, Flavi, and Paramyxovirus for the first time in Bangladesh. We detected CCoV in $4.3 \%$ of tested samples which is lower than reports from other countries such as Italy, China, Turkey, England, Japan, Greece, and Portugal [29,51-54]. Studies conducted in China have also reported variation of $\mathrm{CCoV}$ prevalence in different regions, for example, 26\% in Beijing [55], $28.36 \%$ in Heilongjiang [56], and 23.94\% in Guangdong, Zhejiang, Jiangsu, and Anhui [29].

Though we collected and tested specimens from four different locations, CCoV was detected in Dhaka and Pabna districts only. We investigated the association of CCoV infection with age, sex, ownership status, BCS, and health condition but did not find any significant relations. A similar finding was also reported from Japan [21]. A higher prevalence of $\mathrm{CCoV}$ was found in healthy dogs aged $>1$ year while prevalence was greater among diarrheic dogs in younger animals aged $<1$ year [21]. Previous studies reported that both pup and adult dogs can be infected by $\mathrm{CCoV}$ and develop gastro-enteritis [57].

Besides, the dog population in Bangladesh may carry CCoV asymptomatically $[13,16]$. In some cases, they might have been infected previously but recovered, still shedding $\mathrm{CCoV}$ for several months $[18,22]$. We did not find any severe diarrheic dogs positive for CCoV infection which might be due to genomic mutation in the host, i.e., genomic recombination with other coronaviruses which might lead to shifting and drifting in order to change their pathogenicity and symptoms [21].

In the current study, we detected type II CCoV strains which have already been detected in dogs $[17,21,22,54]$. The conducted analysis demonstrated that newly identified Bangladeshi CCoV strains, BDADP-001, BDADP-002, and BDADAIDP-006 were closely clustered with CCoV-II strains from badger, civet, and dogs from China and UK. Phylogenetic, median-joining network tree and pairwise distance analyses revealed nucleotide similarities of Bangladeshi CCoV strains to FCoV strain NTU156 isolated from cats in 
Taiwan, CCoV strains responsible for human infection in Malaysia and Haiti, and a TGEV strain from pigs. These findings suggest a long history of the transmission cycle from related species in different geographical locations and the recombinant nature of CCoV [13]. The history of human infection with the CCoV strain warrants the threat of zoonotic potentials and CCoV could become the eighth known coronavirus to cause human disease [10].

In this study, we confirmed the presence of CCoVs in dogs by sequencing only a short highly conserved region of the RdRp and NSP14 genes. We could not perform recombinational analysis due to a lack of complete genome or at least full gene (RdRp/NSP14) sequence. Previous studies suggest natural interspecies recombination of FCoVs and CCoV as well as interspecies transmission of CCoVs [58-60]. Besides, several studies reported the human infection of $\mathrm{CCoV}$ and/or novel recombinant $\mathrm{CCoV}$ in multiple countries with acute respiratory symptoms [11,12,61,62]. Gonzalez, Gaelle, et al. claim that dogs might act as "mixing vessels" in which novel viruses with pandemic potential could emerge [63]. Since canines, felines and humans are highly exposed to each other, interspecies transmission of emerging viruses like CCoVs and FCoVs is possible.

Our conducted analyses revealed 96.3-100 sequence homology among Bangladeshi CCoV-II strains and suggest local evolution of the viruses. Phylogenetic analysis of partial RdRp gene confirmed that Bangladeshi CCoV strains were distantly related (72-75\% nt identities) to other Alphacoronavirus species, such as $\mathrm{HCoV}$ (NL63), bat CoVs isolated in Kenya, Mozambique, USA, and rodent $\mathrm{CoV}$ in China (data not shown). Bangladeshi CCoVs showed $~ 58 \%$ sequence homology with SARS-CoV-2 strain 20-02756/2020 isolated from a dog in Hong Kong during the current pandemic outbreak in 2020 (Figure 2).

Coronaviruses have a high potential for the emergence of new strains as with SARS CoV-1 and 2, with genomic mutation and recombination. It has also been assumed that $\mathrm{CCoV}$ is genomically much more complex which might increase the likelihood of novel virus emergence within dogs [13]. Natural infection of SARS-CoV-2 was found in domestic dogs. The first report of a dog infected by SARS-CoV-2 was found in a Pomeranian dog in Hong Kong [8]. The owner of this dog also tested positive for COVID-19 a few days later [8]. Later, several dogs were found to be infected without showing any symptoms in Hong Kong. All of these dogs had a history of mutual living alongside infected humans $[8,55]$. Another dog was infected by its owner in The Netherlands [64].

The main limitation of our study is the small sample size. Considering the lack of data from Bangladesh in this regard, the present study primarily focused on the detection and molecular characterization of circulating viral strains in Bangladesh.

\section{Conclusions}

CCoV has substantial sequence similarity with FCoV. Sharing a habitat with canine and feline species, especially cats, increases the probability of the emergence of novel strains of coronavirus across the species. To understand in further detail the molecular epidemiology and ecology of important viruses in the dog population of Bangladesh, more carefully planned and larger similar studies are required in the future.

Author Contributions: Conceptualization, A.I. and M.Z.R.; methodology, M.E.H., A.I., S.I., M.K.R., M.M. and M.S.A.; software, M.E.H., A.I., S.I. and M.M.; validation, M.E.H., A.I. and M.Z.R.; formal analysis, M.E.H., A.I., S.I. and M.M.; investigation, M.E.H., A.I., S.I. and M.Z.R.; resources, A.I. and M.Z.R.; data curation, S.I. and M.K.R.; writing-original draft preparation, M.E.H., A.I., S.I. and M.M.; writing—review and editing, M.E.H., A.I., S.I., M.K.R., M.M., M.S.A. and M.Z.R.; visualization, M.E.H., A.I. and M.M.; supervision, A.I. and M.Z.R.; project administration, A.I. and M.Z.R.; funding acquisition, A.I. All authors have read and agreed to the published version of the manuscript.

Funding: This study was made possible by the generous support of the American people through the US Agency for International Development Emerging Pandemic Threats PREDICT project (cooperative agreement number: GHN-A-OO-09-00010-00 and AID-OAA-A-14-001).

Institutional Review Board Statement: This study protocol was approved by the research and ethical review committee, icddr, b (protocol: 2008-074), Chattogram Veterinary and Animal Sciences 
University-Animal Experimentation Ethics Committee (protocol: CVASU/Dir (R\&E) AEEC/2015/751) and the Institutional Animal Care and Use Committee of the University of California at Davis (Protocol: 16048).

\section{Informed Consent Statement: Not applicable.}

Data Availability Statement: The data that have been used in this study will be available from the corresponding author upon requests.

Acknowledgments: This study was made possible by the support of the American people through the United States Agency for International Development (USAID) Emerging Pandemic Threats PREDICT project Awards GHN-A-00-09-00010-00 and AID-OAA-A-14-001. We acknowledge Google and the Rockefeller Foundation to support this research. We acknowledge to Jonathan H Epstein, Melinda K Rostral, Emily Hagan, Peter Daszak, Emily S Gurley, Najmul Haider, Ausraful Islam, Abdullah Al Mamun, Abdul Hai, Pitu Biswas and Gafur Sheikh for their contributions to this study. M.E.H., A.I., S.I. and M.Z.R. are supported by the Intramural Research Program of the National Institute of Allergy and Infectious Diseases (NIAID), National Institutes of Health (NIH) under Award Number U01AI153420-01. We also thank the governments of Bangladesh, Canada, Sweden, and the United Kingdom for providing core/unrestricted support to icddr, b. The content is solely the responsibility of the authors and does not necessarily represent the official views of the USA Government.

Conflicts of Interest: The authors declare no conflict of interest.

\section{References}

1. Weiss, S.R.; Navas-Martin, S. Coronavirus Pathogenesis and the Emerging Pathogen Severe Acute Respiratory Syndrome Coronavirus. Microbiol. Mol. Biol. Rev. 2005, 69, 635-664. [CrossRef] [PubMed]

2. de Vries, A.A.; Horzinek, M.C.; Rottier, P.J.; de Groot, R.J. The Genome Organization of the Nidovirales: Similarities and Differences between Arteri-, Toro-, and Coronaviruses. Semin. Virol. 1997, 8, 33-47. [CrossRef] [PubMed]

3. de Groot, R.J.; Baker, S.C.; Baric, R.; Enjuanes, L.; Gorbalenya, A.E.; Holmes, K.V.; Perlman, S.; Poon, L.; Rottier, P.J.M.; Talbot, P.J.; et al. Virus taxonomy: Classification and nomenclature of viruses. In Ninth Report of the International Committee on Taxonomy of Viruses; Springer Science \& Business Media: Berlin/Heidelberg, Germany, 2011; pp. 806-828.

4. Haake, C.; Cook, S.; Pusterla, N.; Murphy, B. Coronavirus Infections in Companion Animals: Virology, Epidemiology, Clinical and Pathologic Features. Viruses 2020, 12, 1023. [CrossRef] [PubMed]

5. Islam, A.; Sayeed, M.A.; Kalam, M.A.; Ferdous, J.; Rahman, M.K.; Abedin, J.; Islam, S.; Shano, S.; Otun Saha, O.; Tahmina Shirin, T.; et al. Molecular epidemiology of SARS-CoV-2 in diverse environmental samples globally. Microorganisms 2021, $9,1696$. [CrossRef] [PubMed]

6. Islam, A.; Ferdous, J.; Sayeed, A.; Rahman, K.; Saha, O.; Hassan, M.M.; Shirin, T. Transmission dynamics and susceptibility patterns of SARS-CoV-2 in domestic, farmed and wild animals: Sustainable One Health surveillance for conservation and public health to prevent future epidemics and pandemics. Transbound. Emerg. Dis. 2021. [CrossRef] [PubMed]

7. Fan, Y.; Zhao, K.; Shi, Z.-L.; Zhou, P. Bat Coronaviruses in China. Viruses 2019, 11, 210. [CrossRef] [PubMed]

8. Sit, T.H.; Brackman, C.J.; Ip, S.M.; Tam, K.W.S.; Law, P.Y.T.; To, E.M.W.; Yu, V.Y.T.; Sims, L.D.; Tsang, D.N.C.; Chu, D.K.W.; et al. Infection of dogs with SARS-CoV-2. Nature 2020, 586, 776-778. [CrossRef]

9. Patterson, E.I.; Elia, G.; Grassi, A.; Giordano, A.; Desario, C.; Medardo, M.; Smith, S.L.; Anderson, E.R.; Prince, T.; Patterson, G.T.; et al. Evidence of exposure to SARS-CoV-2 in cats and dogs from households in Italy. Nat. Commun. 2020, 11, 1-5. [CrossRef] [PubMed]

10. Islam, A.; Ferdous, J.; Islam, S.; Sayeed, A.; Choudhury, S.D.; Saha, O.; Hassan, M.M.; Shirin, T. Evolutionary Dynamics and Epidemiology of Endemic and Emerging Coronaviruses in Humans, Domestic Animals, and Wildlife. Viruses 2021, $13,1908$. [CrossRef] [PubMed]

11. Vlasova, A.N.; Diaz, A.; Damtie, D.; Xiu, L.; Toh, T.-H.; Lee, J.S.-Y.; Saif, L.J.; Gray, G.C. Novel Canine Coronavirus Isolated from a Hospitalized Pneumonia Patient, East Malaysia. Clin. Infect. Dis. 2021, ciab456. [CrossRef]

12. Lednicky, J.A.; Tagliamonte, M.S.; White, S.K.; Blohm, G.M.; Alam, M.; Iovine, N.M.; Salemi, M.; Mavian, C.; Morris, J.G. Isolation of a Novel Recombinant Canine Coronavirus from a Visitor to Haiti: Further Evidence of Transmission of Coronaviruses of Zoonotic Origin to Humans. Clin. Infect. Dis. 2021, ciab924. [CrossRef] [PubMed]

13. Licitra, B.N.; Duhamel, G.E.; Whittaker, G.R. Canine Enteric Coronaviruses: Emerging Viral Pathogens with Distinct Recombinant Spike Proteins. Viruses 2014, 6, 3363-3376. [CrossRef] [PubMed]

14. Pratelli, A.; Martella, V.; Decaro, N.; Tinelli, A.; Camero, M.; Cirone, F.; Elia, G.; Cavalli, A.; Corrente, M.; Greco, G.; et al. Genetic diversity of a canine coronavirus detected in pups with diarrhoea in Italy. J. Virol. Methods 2003, 110, 9-17. [CrossRef]

15. Decaro, N.; Buonavoglia, C. An update on canine coronaviruses: Viral evolution and pathobiology. Vet. Microbiol. 2008, 132, 221-234. [CrossRef] [PubMed] 
16. Zappulli, V.; Caliari, D.; Cavicchioli, L.; Tinelli, A.; Castagnaro, M. Systemic fatal type II coronavirus infection in a dog: Pathological findings and immunohistochemistry. Res. Vet. Sci. 2007, 84, 278-282. [CrossRef]

17. Decaro, N.; Martella, V.; Ricci, D.; Elia, G.; Desario, C.; Campolo, M.; Cavaliere, N.; Di Trani, L.; Tempesta, M.; Buonavoglia, C. Genotype-specific fluorogenic RT-PCR assays for the detection and quantitation of canine coronavirus type I and type II RNA in faecal samples of dogs. J. Virol. Methods 2005, 130, 72-78. [CrossRef] [PubMed]

18. Pratelli, A.; Elia, G.; Martella, V.; Tinelli, A.; DeCaro, N.; Marsilio, F.; Buonavoglia, D.; Tempesta, M.; Buonavoglia, C. M gene evolution of canine coronavirus in naturally infected dogs. Vet. Rec. 2002, 151, 758-761.

19. Decaro, N.; Desario, C.; Elia, G.; Mari, V.; Lucente, M.S.; Cordioli, P.; Colaianni, M.L.; Martella, V.; Buonavoglia, C. Serological and molecular evidence that canine respiratory coronavirus is circulating in Italy. Vet. Microbiol. 2007, 121, 225-230. [CrossRef] [PubMed]

20. Yachi, A.; Mochizuki, M. Survey of Dogs in Japan for Group 2 Canine Coronavirus Infection. J. Clin. Microbiol. 2006, 44, 2615-2618 [CrossRef]

21. Takano, T.; Yamashita, S.; Murata-Ohkubo, M.; Satoh, K.; Doki, T.; Hohdatsu, T. Prevalence of canine coronavirus (CCoV) in dog in Japan: Detection of CCoV RNA and retrospective serological analysis. J. Vet. Med Sci. 2016, 78, 341-345. [CrossRef] [PubMed]

22. Erles, K.; Brownlie, J. Sequence analysis of divergent canine coronavirus strains present in a UK dog population. Virus Res. 2009, 141, 21-25. [CrossRef]

23. Rahaman, K. Free roaming dogs: A threat to public health. Int. J. Epidemiol. Res. 2017, 4, 182-184. [CrossRef]

24. Hossain, M.; Ahmed, K.; Marma, A.S.P.; Hossain, S.; Ali, M.A.; Shamsuzzaman, A.K.M.; Nishizono, A. A survey of the dog population in rural Bangladesh. Prev. Vet. Med. 2013, 111, 134-138. [CrossRef]

25. -Tenzin, T.; Ahmed, R.; Debnath, N.C.; Ahmed, G.; Yamage, M. Free-Roaming Dog Population Estimation and Status of the Dog Population Management and Rabies Control Program in Dhaka City, Bangladesh. PLoS Negl. Trop. Dis. 2015, 9, e0003784. [CrossRef]

26. Azhar, E.I.; El-Kafrawy, S.A.; Farraj, S.A.; Hassan, A.M.; Al-Saeed, M.S.; Hashem, A.M.; Madani, T.A. Evidence for Camel-toHuman Transmission of MERS Coronavirus. N. Engl. J. Med. 2014, 370, 2499-2505. [CrossRef]

27. Bolles, M.; Donaldson, E.; Baric, R. SARS-CoV and emergent coronaviruses: Viral determinants of interspecies transmission. Curr. Opin. Virol. 2011, 1, 624-634. [CrossRef]

28. Navarro, R.; Nair, R.; Peda, A.; Aung, M.S.; Ashwinie, G.S.; Gallagher, C.A.; Malik, Y.S.; Kobayashi, N.; Ghosh, S. Molecular characterization of canine parvovirus and canine enteric coronavirus in diarrheic dogs on the island of St. Kitts: First report from the Caribbean region. Virus Res. 2017, 240, 154-160. [CrossRef] [PubMed]

29. He, H.-J.; Zhang, W.; Liang, J.; Lu, M.; Wang, R.; Li, G.; He, J.-W.; Chen, J.; Xing, G.; Chen, Y. Etiology and genetic evolution of canine coronavirus circulating in five provinces of China, during 2018-2019. Microb. Pathog. 2020, 145, 104209. [CrossRef] [PubMed]

30. Haun, B.K.; Kamara, V.; Dweh, A.S.; Garalde-Machida, K.; Forkay, S.S.E.; Takaaze, M.; Namekar, M.; Wong, T.A.S.; Woto, A.E.R.B.-G.; Humphreys, P.; et al. Serological evidence of Ebola virus exposure in dogs from affected communities in Liberia: A preliminary report. PLoS Negl. Trop. Dis. 2019, 13, e0007614. [CrossRef]

31. Andersson, E.; Kendall, A.; Url, A.; Auer, A.; Leschnik, M. The first RT-qPCR confirmed case of tick-borne encephalitis in a dog in Scandinavia. Acta Vet. Scand. 2020, 62, 1-6. [CrossRef] [PubMed]

32. Montagnaro, S.; Piantedosi, D.; Ciarcia, R.; Loponte, R.; Veneziano, V.; Fusco, G.; Amoroso, M.G.; Ferrara, G.; Damiano, S.; Iovane, G.; et al. Serological Evidence of Mosquito-Borne Flaviviruses Circulation in Hunting Dogs in Campania Region, Italy. Vector-Borne Zoonotic Dis. 2019, 19, 142-147. [CrossRef]

33. Evermann, J.F.; Lincoln, J.D.; McKiernan, A.J. Isolation of a paramyxovirus from the cerebrospinal fluid of a dog with posterior paresis. J. Am. Vet. Med Assoc. 1980, 177, 1132-1134.

34. Macartney, L.; Cornwell, H.J.; McCandlish, I.A.; Thompson, H. Isolation of a novel paramyxovirus from a dog with enteric disease. Vet. Record 1985, 117, 205-207. [CrossRef] [PubMed]

35. Kempf, C.; Schulz, B.S.; Strauch, C.; Sauter-Louis, C.; Truyen, U.; Hartmann, K. Virus detection, clinical signs, and laboratory findings in dogs with acute hemorrhagic diarrhea: A retrospective study of 935 cases. Tierarztl Prax Ausg K Kleintiere Heimtiere 2010, 38, 79-86. [PubMed]

36. Islam, A.; Rahman, M.L.; Islam, S.; Debnath, P.; Alam, M.; Hassan, M.M. Sero-prevalence of visceral leishmaniasis (VL) among dogs in VL endemic areas of Mymensingh district, Bangladesh. J. Adv. Vet. Anim. Res. 2017, 4, 241-248. [CrossRef]

37. Khan, S.; Epstein, J.; Olival, K.; Hassan, M.; Hossain, M.; Rahman, K.; Elahi, M.; Mamun, M.; Haider, N.; Yasin, G.; et al. Hematology and serum chemistry reference values of stray dogs in Bangladesh. Open Vet. J. 2011, 1, 13-20. [PubMed]

38. Rakib, T.M.; Islam, S.; Azam, N.E.; Islam, S.; Al Faruq, A.; Das, T.; Akter, L.; Hassan, M.M.; Hossain, M.A. Multidrug Resistance Pattern of Salmonella Typhimurium Isolated from Rectal Swabs of Stray Dogs at Chittagong Metropolitan Area (CMA), Bangladesh. Microbiol. Res. J. Int. 2018, 25, 1-11. [CrossRef]

39. Fábrega, L.; Restrepo, C.M.; Torres, A.; Smith, D.; Chan, P.; Pérez, D.; Cumbrera, A.; Caballero, E.Z. Frequency of Toxoplasma gondii and Risk Factors Associated with the Infection in Stray Dogs and Cats of Panama. Microorganisms 2020, 8, 927. [CrossRef]

40. Burns, K.; Renda-Francis, L. Textbook for the Veterinary Assistant; John Wiley \& Sons: Hoboken, NJ, USA, 2014.

41. Gorrel, C. Veterinary Dentistry for the General Practitioner; Saunders Ltd.: St. Louis, MO, USA, 2014. [CrossRef] 
42. Smith, L.M. The Impact of Dog Population Management on Free-Roaming Dog Population Dynamics, Health and Welfare; University of Leeds: Leeds, UK, 2020.

43. Moureau, G.; Temmam, S.; Gonzalez, J.-P.; Charrel, R.; Grard, G.; De Lamballerie, X. A Real-Time RT-PCR Method for the Universal Detection and Identification of Flaviviruses. Vector-Borne Zoonotic Dis. 2007, 7, 467-478. [CrossRef]

44. Zhai, J.; Palacios, G.; Towner, J.S.; Jabado, O.; Kapoor, V.; Venter, M.; Grolla, A.; Briese, T.; Paweska, J.; Swanepoel, R.; et al. Rapid Molecular Strategy for Filovirus Detection and Characterization. J. Clin. Microbiol. 2007, 45, 224-226. [CrossRef] [PubMed]

45. Tong, S.; Chern, S.-W.W.; Li, Y.; Pallansch, M.A.; Anderson, L.J. Sensitive and Broadly Reactive Reverse Transcription-PCR Assays to Detect Novel Paramyxoviruses. J. Clin. Microbiol. 2008, 46, 2652-2658. [CrossRef]

46. Quan, P.-L.; Firth, C.; Street, C.; Henriquez, J.A.; Petrosov, A.; Tashmukhamedova, A.; Hutchison, S.K.; Egholm, M.; Osinubi, M.O.V.; Niezgoda, M.; et al. Identification of a Severe Acute Respiratory Syndrome Coronavirus-Like Virus in a Leaf-Nosed Bat in Nigeria. mBio 2010, 1, e00208-10. [CrossRef] [PubMed]

47. Watanabe, S.; Masangkay, J.S.; Nagata, N.; Morikawa, S.; Mizutani, T.; Fukushi, S.; Alviola, P.; Omatsu, T.; Ueda, N.; Iha, K.; et al Bat Coronaviruses and Experimental Infection of Bats, the Philippines. Emerg. Infect. Dis. 2010, 16, 1217-1223. [CrossRef]

48. Anthony, S.J.; Johnson, C.K.; Greig, D.J.; Kramer, S.; Che, X.; Wells, H.; Hicks, A.L.; Joly, D.O.; Wolfe, N.D.; Daszak, P.; et al. Global patterns in coronavirus diversity. Virus Evol. 2017, 3, vex012. [CrossRef]

49. Hall, T. BioEdit: A user-friendly biological sequence alignment editor and analysis program for Windows 95/98/NT. Nucleic Acids Symp. Ser. 1999, 41, 95-98.

50. Hasegawa, M.; Kishino, H.; Yano, T.-A. Dating of the human-ape splitting by a molecular clock of mitochondrial DNA. J. Mol. Evol. 1985, 22, 160-174. [CrossRef] [PubMed]

51. Ntafis, V.; Mari, V.; Decaro, N.; Papanastassopoulou, M.; Pardali, D.; Rallis, T.S.; Kanellos, T.; Buonavoglia, C.; Xylouri, E. Canine coronavirus, Greece. Molecular analysis and genetic diversity characterization. Infect. Genet. Evol. 2013, 16, 129-136. [CrossRef] [PubMed]

52. Bandai, C.; Ishiguro, S.; Masuya, N.; Hohdatsu, T.; Mochizuki, M. Canine Coronavirus Infections in Japan: Virological and Epidemiological Aspects. J. Vet. Med. Sci. 1999, 61, 731-736. [CrossRef] [PubMed]

53. DeCaro, N.; Mari, V.; Elia, G.; Addie, D.D.; Camero, M.; Lucente, M.S.; Martella, V.; Buonavoglia, C. Recombinant Canine Coronaviruses in Dogs, Europe. Emerg. Infect. Dis. 2010, 16, 41-47. [CrossRef]

54. Yesilbag, K.; Yilmaz, Z.; Torun, S.; Pratelli, A. Canine Coronavirus Infection in Turkish Dog Population. J. Vet. Med. Ser. B 2004, 51, 353-355. [CrossRef]

55. Lu, S.; Zhang, D.; Zhou, J.; Xia, Z.; Lin, D.; Lou, Y.; Tan, W.; Qin, K. Prevalence and phylogenetic characterization of canine coronavirus from diseased pet dogs in Beijing, China. Sci. China Life Sci. 2016, 59, 860-862. [CrossRef]

56. Wang, X.; Li, C.; Guo, D.; Wei, S.; Geng, Y.; Wang, E.; Wang, Z.; Zhao, X.; Su, M.; Liu, Q.; et al. Co-Circulation of Canine Coronavirus I and IIa/b with High Prevalence and Genetic Diversity in Heilongjiang Province, Northeast China. PLoS ONE 2016, 11, e0146975. [CrossRef] [PubMed]

57. Sakulwira, K.; Vanapongtipagorn, P.; Theamboonlers, A.; Oraveerakul, K.; Poovorawan, Y. Prevalence of canine coronavirus and parvovirus infections in dogs with gastroenteritis in Thailand. Vet. Med. 2003, 48, 163-168. [CrossRef]

58. Terada, Y.; Matsui, N.; Noguchi, K.; Kuwata, R.; Shimoda, H.; Soma, T.; Mochizuki, M.; Maeda, K. Emergence of Pathogenic Coronaviruses in Cats by Homologous Recombination between Feline and Canine Coronaviruses. PLoS ONE 2014, 9, e106534. [CrossRef] [PubMed]

59. Nguyen, T.L.; Thi, H.H.P. Genome-wide comparison of coronaviruses derived from veterinary animals: A canine and feline perspective. Comp. Immunol. Microbiol. Infect. Dis. 2021, 76, 101654. [CrossRef] [PubMed]

60. Lin, C.-N.; Chang, R.-Y.; Su, B.-L.; Chueh, L.-L. Full genome analysis of a novel type II feline coronavirus NTU156. Virus Genes 2013, 46, 316-322. [CrossRef] [PubMed]

61. Silva, C.; Mullis, L.B.; Pereira, O.; Saif, L.J.; Vlasova, A.; Zhang, X.; Owens, R.J.; Paulson, D.; Taylor, D.; Haynes, L.M.; et al Human Respiratory Coronaviruses Detected In Patients with Influenza-Like Illness in Arkansas, USA. Virol. Mycol. 2014, 2014, 004. [CrossRef] [PubMed]

62. Xiu, L.; Binder, R.A.; Alarja, N.A.; Kochek, K.; Coleman, K.K.; Than, S.T.; Bailey, E.S.; Bui, V.N.; Toh, T.-H.; Erdman, D.D.; et al. A RT-PCR assay for the detection of coronaviruses from four genera. J. Clin. Virol. 2020, 128, 104391. [CrossRef] [PubMed]

63. Gonzalez, G.; Marshall, J.; Morrell, J.; Robb, D.; McCauley, J.W.; Perez, D.R.; Parrish, C.R.; Murcia, P.R. Infection and Pathogenesis of Canine, Equine, and Human Influenza Viruses in Canine Tracheas. J. Virol. 2014, 88, 9208-9219. [CrossRef]

64. Delong, J. Dutch Minister Confirms Dog, Three Cats Have Caught Novel Coronavirus I Reuters. 2020. Available online: https://www.reuters.com/article/us-health-coronavirus-netherlands-pets-idUSKBN22R2EN (accessed on 17 September 2021). 